\title{
ZNACZENIE JĘZYKOWE NORMY PRAWNEJ W POZNAŃSKO-SZCZECIŃSKIEJ SZKOLE TEORII PRAWA W ŚWIETLE PRAGMATYZMU ANALITYCZNEGO
}

To zaskakujące, że fundamentalne dla teorii i filozofii prawa pojęcie normy prawnej, w szczególności jej językowego znaczenia, wciąż jest przedmiotem nierozwiązanego sporu. Spór ten ma charakter par excellence epistemologiczny. Wobec takiego ujęcia wydaje się, że ulepszenie narzędzi z gruntu filozofii języka może pozwolić teoretykowi prawa na sprawniejsze radzenie sobie choćby z ustaleniem znaczenia normy prawnej. Jedno ze stanowisk $\mathrm{w}$ tym sporze zostało przedstawione w ramach tzw. poznańsko-szczecińskiej szkoły teorii prawa (dalej: Szkoła). Przedmiotem niniejszego artykułu będzie więc w pierwszej kolejności próba rekonstrukcji koncepcji zastanych i wypracowanych przez Zygmunta Ziembińskiego, Macieja Zielińskiego, Leszka Nowaka i Wojciecha Patryasa. Nie ma żadnej wattpliwości, że Szkoła w ramach swojej działalności szeroko korzystała z osiagnięć filozofii analitycznej, w szczególności zaś myśli Kazimierza Ajdukiewicza, stąd ten związek również zostanie przybliżony w dalszej części tekstu.

Ostatecznie zwrócę uwagę na rolę pragmatyzmu analitycznego Roberta B. Brandoma w przezwyciężaniu trudności ujawnionych na gruncie przyjmowanych w Szkole założeń. Zajmę się również tym ujęciem pragmatyzmu analitycznego, które w polskiej teorii prawa zaproponował Maciej Dybowski. Kierunek ten w pożyteczny sposób rozwija analityczne intuicje występujące w Szkole. Podzielam pogląd Dybowskiego, że „najważniejszym wyzwaniem, jakie programom pozostającym w nurcie klasycznej analizy rzucił w drugiej połowie XX w. pragmatyzm, jest próba przesunięcia ciężaru rozważań filozoficznych dotyczących tego, co w polskim prawoznawstwie zwykło się określać mianem płaszczyzny logiczno-językowej, z pojęcia znaczenia ku pojęciu użycia [wyróżnienie - W.R.]"1. Oznacza to potrzebę zweryfikowania założeń semantycznych przyjmowanych w Szkole, w szczególności przez zwrócenie uwagi na związek między ustalaniem znaczenia a praktyką posługiwania się językiem.

${ }^{1}$ Dybowski (2017a): 21. 


\section{ZNACZENIE JĘZYKOWE NORMY PRAWNEJ W RAMACH SZKOLY}

Prace teoretycznoprawne Zygmunta Ziembińskiego miały na celu przede wszystkim uporządkowanie aparatury pojęciowej zastanej na badanym polu. U podstaw tychże działań legło przekonanie, że owa praca wstępna jest „warunkiem koniecznym tego, by owocnie stawiać i rozwiązywać problemy teoretycznoprawne"2. Majac na uwadze wyraźnie twórczy charakter porządkowania aparatury pojęciowej przez Ziembińskiego, uznaję, że rekonstrukcję koncepcji znaczenia językowego normy należy rozpoczać od omówienia od tego autora. Podkreślenia wymaga, że zagadnienie znaczenia językowego normy prawnej $\mathrm{w}$ zasadzie nie było poruszane w ramach Szkoły jako zagadnienie samoistne (odmiennie niż w przypadku ujęcia Jerzego Wróblewskiego) ${ }^{3}$. Odnosi się ono zazwyczaj do poszczególnych problemów językowo-logicznej płaszczyzny badania prawa. Powoduje to, że analizie należy poddać cały konglomerat poglądów.

Opublikowany w 1960 r. artykuł Ziembińskiego Przepis prawny a norma prawna stał się tekstem programowym Szkoły. Po latach uczniowie Ziembińskiego napisali, że „na nim [rozróżnieniu pojęciowym przepisu prawnego i normy prawnej - W.R.] opiera się przyjęta przez jej [Szkoły - W.R.] przedstawicieli wizja prawa, a można bez przesady powiedzieć, że właściwie całość jej dorobku teoretycznego" ${ }^{\text {. }}$. Nie powinno to dziwić, tym bardziej że już Znamierowski pisał, iż ,zagadnienie normy postępowania, w szczególności normy prawnej, jest dla teorji prawa zagadnieniem niemal centralnem, a może nawet stricto sensu centralnem [...]"5.

We wspomnianym artykule programowym Ziembiński prezentuje pogląd, że „przepisy wyrażają normy prawne, to jest wskazania, co wedle woli ustawodawcy powinna czynić pewna osoba, wskazania, że ktoś ma obowiązek takiego a takiego zachowania w pewnych okolicznościach (względnie - że nie ma obowiązku). Normy są treścią przepisów”6. Tekst ten stanowi jedynie wstęp do zrekonstruowania koncepcji znaczenia językowego normy leżącej u podstaw teorii prawa szkoły. Ziembiński wskazuje w nim bowiem, w jaki sposób w przepisach wyrażane sa normy prawne (m.in. wprowadzone zostaje rozróżnienie na przepisy właściwe i interpretacyjne). Zgodnie z tym można wskazanie to odwrócić i dokonać analizy procesu odtwarzania norm prawnych z przepisów - powiedzieć, jak z takich a takich przepisów wyprowadzić normę odpowiadającą schematowi: „w warunkach $W$ każda osoba mająca właściwości $T$ jest obowiązana (nie jest obowiązana) czynić $C$ ”.

Jeśli norma prawna jest treścia przepisu prawnego (lub przepisów prawnych), jak postuluje Ziembiński, to konsekwencja tej tezy wydaje się twierdzenie, że znaczenie językowe norm prawnych jest w pewien sposób zapośred-

\footnotetext{
${ }^{2}$ Wronkowska (2010): 337.

3 Zob. Wróblewski (1959).

${ }^{4}$ Czepita, Wronkowska, Zieliński (2013): 9.

5 Znamierowski (1934): 20.

6 Ziembiński (1960): 105.

7 Ziembiński (1960): 105.
} 
niczone w znaczeniu językowym przepisów prawnych. Powyższą tezę oddaje następująca definicja wyrażenia „interpretacja tekstu prawnego” sformułowana przez Zielińskiego: „Interpretacja tekstu prawnego polega na zastapieniu tekstu prawnego przy pomocy reguł $R$ zbiorem norm postępowania równoznacznym [wyróżnienie - W.R.] na gruncie reguł $R$ z tekstem prawnym"8.

Norma prawna jako wypowiedź rekonstruowana z przepisów prawnych zbudowana będzie chociażby ze słownictwa zapożyczonego z przepisów. Co więcej, „przepis, który bezpośrednio wysławia jakaśs normę postępowania, może ubocznie zawierać w sobie elementy, dające wyjaśnienie co do sposobu

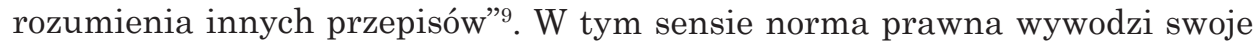
znaczenie z kontekstu (redukowalnego do określonych elementów) tworzonego przez przepisy prawne. Ziembiński i Zieliński wyraźnie postulowali przy tym rozróżnienie „języka przepisów prawnych” oraz „języka norm prawnych” ${ }^{10}$. Pierwszy z nich dodaje zaś, że „właściwości języka tekstów prawnych i języka norm prawnych nie są identyczne, przy czym kształt wypowiedzi języka norm prawnych w znacznym stopniu uzależniony jest od przyjmowanych reguł wykładni” ${ }^{11}$. Można więc wnioskować, że przyjęty zostaje pogląd o niemożliwości ustalenia obiektywnego znaczenia językowego norm prawnych. W tym sensie przyjęcie $\mathrm{w}$ danej grupie interpretatorów jednego zespołu reguł pozwala wyłacznie na uzyskanie intersubiektywnego wyniku wykładni. Nadto nie przesadza się, czy można w ogóle mówić o obiektywności znaczenia językowego norm.

Przyjmując, że „problemy dotyczące norm prawnych [...] uzyskują konkretne sformułowanie dopiero przy przyjęciu określonego paradygmatu metodologicznego dokonywania wykładni przepisów”"12, należy skonstatować, że wzorca takiego dostarcza na gruncie Szkoły derywacyjna koncepcja wykładni prawa. Zieliński wskazuje, że „wykładnia w ujęciu derywacyjnym jest przede wszystkim wykładnią pojmowaną pragmatycznie, tj. jako zespół pewnych czynności zmierzających do zrozumienia przepisów prawnych, więc jako zespół czynności zmierzających do odtworzenia norm prawnych z przepisów prawnych i do dokonania ich jednoznacznej percepcji”" ${ }^{13}$. Nadto ma ona charakter normatywny, gdyż adresuje ona do interpretatora określone reguły interpretacyjne, które są „dyrektywami celowościowymi wskazującymi sposób postępowania, który jest skuteczny dla osiaggnięcia celu interpretacyjnego (a więc w ostateczności dla ustalenia sensu odtworzonej z przepisów prawnych normy prawnej)"14. Niejasne pozostaje, czy w ramach Szkoły wprowadzone zostało Fregowskie rozróżnienie na Sinn oraz Bedeutung. Wydaje się, że wyrażenie „sens” w przywołanej wypowiedzi (a także innych wypowiedziach podobnych) zostało użyte jako synonim wyrażenia „znaczenie” - nie chodzi bowiem o ustalenie tego, co

${ }^{8}$ Zieliński (1972): 27.

${ }^{9}$ Ziembiński (1960): 110.

${ }^{10}$ Ziembiński (1974): 212; Zieliński (1972): 8.

${ }^{11}$ Ziembiński (1974): 212.

${ }^{12}$ Zieliński, Ziembiński (1988): 77.

13 Zieliński (2017): 236.

${ }^{14}$ Zieliński (2017): 250-251. Autor ten podaje „dyrektywy postępowania interpretacyjnego” w części piątej cytowanej pozycji. 
między przedmiotem a znakiem (Sinn w rozumieniu Fregego), a o ostateczna możliwość ustalenia odniesienia, znaczenia przepisów.

To na gruncie derywacyjnej koncepcji wykładni wyznaczony został zbiór reguł przyporządkowywania znaczeń określonym wyrażeniom. W omawianym przypadku reguły te zostały wyprowadzane przez przedstawicieli Szkoły z kultury prawnej ${ }^{15}$, moga być one wyrażane również w przepisach prawnych, np. w formie definicji legalnych. Ziembiński przywołuje dwa stanowiska (ujęcie normatywne i nienormatywne) dotyczace roli przepisów o charakterze definicyjnym, które sprowadzają się do rozstrzygnięcia tego, kto i w jaki sposób ma ustalać znaczenie wyrażeń w nich zdefiniowanych ${ }^{16}$. Jego zdaniem zarzut przeciwko takiemu zarysowaniu problemu definicji może dotyczyć tego, że definicje pojęć systematyzacyjnych, instytucji nie sa konstruowane w postaci definicji równościowych, lecz w sposób zwany w logice definicja przez postulaty, tj. przez wzorcowe posługiwanie się danym wyrazem, gdzie rolę wzorcowych zdań spełniaja w tym przypadku przepisy ustawy. Nie jest jednak jasne, czy mamy tutaj do czynienia wyłącznie ze znaczeniem językowym określonych wyrażeń czy właśnie znaczeniem przepisu - norma.

Owe definicje określa się jako nakazy wyrażone w tekstach prawnych, które wskazuja, aby dane wyrażenie (słowo, zwrot językowy) rozumieć w określony sposób ${ }^{17}$. Według Ziembińskiego w ten sposób „przepisy prawne formułuja definicje ustanawiające w sposób wyraźny wiążące reguły znaczeniowe w odniesieniu do języka prawnego"18. Dodaje on w tym zakresie, że „metajęzykowy charakter definicji legalnych dostrzegają niektórzy przedstawiciele szczegółowych nauk prawnych, traktując definicje legalne jako "przednawiasowy komentarz « do norm prawnych, w których definiowany termin występuje"19. Definicje legalne sa jednak regułami nietypowymi. Trzymając się zaś podziału na pragmatyczne reguły interpretacyjne i apragmatyczne reguły interpretacyjne, należy wskazać, że zdaniem Zielińskiego definicje legalne jako reguły pełnią jednocześnie obie te role. Jego zdaniem są one zarówno „wskazówkami informującymi o znaczeniu danego zwrotu”, a także „stanowią one podstawę do odtworzenia z nich norm prawnych pełniących rolę prawnie wiążących reguł interpretacyjnych" 20 .

15 Jak wskazuje Ziembiński ([2002]: 232): „dyrektywy interpretacyjne, reguły inferencyjne i kolizyjne są częściowo sformułowane w przepisach prawnych dotyczących sposobu rozumienia innych przepisów (a więc w metaprzepisach); przeważnie jednak są one wytworem tradycji prawniczej przyjętej w akademickiej doktrynie prawniczej [...] czy też orzecznictwie, zwłaszcza orzecznictwie sądów”.

16 Ujęcie nienormatywne, jak wskazuje Ziembiński, umacnia pogląd o współstanowieniu prawa przez jurysprudencję, ujęcie normatywne wskazuje, że znaczenie jest ustalane przez normodawcę. W ramach Szkoły przyjęto to drugie ujęcie. Jak ujął to Zieliński ([1972]: 20, przyp. 32): „normatywność tzw. definicji legalnych przyjmuje się w oparciu o założenia dotyczące racjonalności ustawodawcy”.

$17 \mathrm{~W}$ niniejszej pracy nie podejmuję problematyki sposobów definiowania wyrażeń, którymi posługuje się prawodawca w tekstach prawnych. Szerzej na ten temat z perspektywy logiki tradycyjnej np. Patryas (1997).

18 Ziembiński (2002): 232.

19 Ziembiński (1980): 310 wraz z cytowaną tam literatura.

20 Zieliński (2017): 238. 
Ten ostatni pogląd stał się przedmiotem krytyki ze strony Dybowskiego, który wskazał, że „definicja legalna nie pełni żadnej istotnej z punktu widzenia wykładni prawa roli apragmatycznej" ${ }^{21}$. Jego zdaniem na gruncie derywacyjnej koncepcji wykładni nie trzeba wskazywać na podwójną rolę, jaka moga one pełnić, i zwraca szczególną uwagę na dwie trudności z tym związane. Podstawowa polega na tym, że nie istnieje praktyczna możliwość rozróżnienia, kiedy definicja legalna pełni rolę pragmatyczną („należy rozumieć”), a kiedy apragmatyczną (,tak a tak należy rozumieć”). Na poparcie swojej tezy formułuje on trzy argumenty. Pierwszy, odwołujacy się do analizy wyrażenia „rozumieć dany zwrot”, w odniesieniu do założeń derywacyjnej koncepcji wykładni, prowadzi do wniosku, że na gruncie tej koncepcji rozumienie zwrotów ma charakter nie semantyczny, lecz de facto syntaktyczny ${ }^{22}$. To zaś powoduje, że definicje legalne jako reguły interpretacyjne nakazują używać zwrotu definiowanego w sposób anaforyczny. Drugi argument odwołuje się do rozróżnienia reguł apragmatycznych słownikowych i reguł apragmatycznych kontekstowych oraz do tez Zielińskiego, że pierwsze z nich są bardziej pierwotne niż drugie. Zdaniem Dybowskiego: „w przypadku definicji legalnych - inaczej niż w przypadku definicji sformułowanych w słownikach języka powszechnego - definicje te nie sa językowo bardziej pierwotne niż reguły kontekstowe, ponieważ definicja legalna jako reguła pragmatyczna wykładni wyznacza rozumienie anaforyczne (zastępowalność syntaktyczna) oraz »jednokontekstowość« (i »jedynokontekstowość«) posługiwania się zwrotem definiujaccym”23. To rozumowanie wzmacnia argument z językowego sformułowania przepisów, gdzie „wskazanie na użycie i wielokrotność wystapienia odnosi się do jednego kontekstu, w jakim należy dokonać zastapienia danego zwrotu"24. Ostatni argument ma charakter argumentu ze świata możliwego i prowadzi Dybowskiego do konkluzji, że „definicje legalne mogą wprawdzie pełnić w zasobie języka jakieś role apragmatyczne, lecz w wykładni ujmowanej tak, jak to ma miejsce w koncepcji derywacyjnej, albo nie pełnią one tej roli w ogóle, albo jest to rola pomijalna"25.

Dybowski zauważa jeszcze drugą trudność dotycząca odpowiedniego uwzględnienia znaczenia wynikającą z postulowanej dwoistości ról definicji legalnych. Uwzględnienie odbywa się bowiem w określonym „momencie interpretacyjnym"26. Dybowski podkreśla, że moment ten odnosi się zarówno do płaszczyzny obowiązywania prawa, jak i płaszczyzny znaczenia nazw w tekście prawnym ${ }^{27}$. W tym sensie interpretator przypatruje się tekstowi prawnemu, a więc także językowi prawnemu, w którym jest ów tekst sformułowany w konkretnym momencie jego istnienia. W tym momencie język posiada określony zasób reguł jego interpretacji, określone słownictwo i określone

\footnotetext{
${ }^{21}$ Dybowski (2017c): 115.

22 Dybowski (2017c): 119-120.

23 Dybowski (2017c): 121.

${ }^{24}$ Dybowski (2017c): 122.

25 Dybowski (2017c): 124.

${ }_{26}$ Por. Czepita (2010): 230, 252 n.

27 Por. Dybowski (2017c): 128.
} 
znaczenia wyrażeń ${ }^{28}$. Idąc o krok dalej, przywołując przy tym teoretyczne postulaty Saula Kripkego, Maciej Dybowski wskazuje, że „identyfikacji właściwego momentu interpretacyjnego powinna w przypadku definicji legalnych towarzyszyć również identyfikacja właściwego kręgu użytkowników takich definicji”"29. Odwołując się do założeń koncepcji derywacyjnej, podsumowuje, że „sięganie przez interpretatora po definicje słownikowe to nic innego jak oparcie się w wykładni na swego rodzaju opiniach biegłych z dziedziny semantyki. [...] Ostatecznie zatem główny poruszony tu problem definicji legalnych jako reguł pragmatycznych wykładni nie polega na tym, jakie działania wyznaczać ma interpretatorowi, lecz z kim powinien on współdziałać w realizowaniu tych działań"30. Powyższa krytyka jest interesująca, ponieważ podkreśla dylematy wynikające z przyjętego na gruncie Szkoły stanowiska semantycznego, jednocześnie wskazując na intuicję związaną z petryfikacja pewnych fragmentów praktyki językowej w formie definicji słownikowych. W tym sensie pragmatyczna rola definicji legalnych polegałaby na wskazaniu miejsca, w którym należy szukać relewantnych użyć danego wyrażenia. Zastępowalność syntaktyczna nie jest równoznaczna z poprawnym przypisywaniem znaczenia językowego. Na gruncie Brandomowskiego pragmatyzmu zastapienie takie podlegałoby sprawdzeniu za pomoca zdolności użytkowników danego języka do reagowania różnicującego. Sprawdzenie takie dokonuje się przy tym w ramach szerszej praktyki językowej obejmującej co najmniej stwierdzenia (asercje).

Przypomnieć należy, że ujmowanie w Szkole znaczenia językowego wydaje się konsekwencją dwóch założeń: po pierwsze, że pomiędzy przepisem prawnym a normą prawną istnieje związek o charakterze treściowym, po drugie zaś, z wyraźnego rozróżnienia przepisu normy i wskazania reguł odtwarzania norm na podstawie przepisów. Tak zarysowany związek między przepisem prawnym a norma prawną nie ma bowiem charakteru koniecznego, jest więc przypadkowy, w szczególności nie wynika z natury tych pojęć. Istnieje bowiem teoretyczna możliwość skonstruowania takiej teorii prawa, która zakłada np. istnienie norm prawnych, lecz nieistnienie przepisów prawnych lub też takich, które normę utożsamiaja z bytem pozajęzykowym, a więc nieujmowanym w języku, a tym samym niedajacym się wyinterpretować z przepisów prawnych ${ }^{31}$.

Wynik wykładni prawa w derywacyjnej koncepcji wykładni - norma prawna jako wypowiedź - musi zostać odkodowany przez interpretatora. W tym sensie, jak podkreśla Ziembiński, „mówiąc [...] o jakiejś jednej normie, ujmujemy oczywiście rozważaną wypowiedź (wszelki egzemplarz wypowiedzi danego kształtu) w jakimś jednym określonym znaczeniu; chodzi więc o wypowiedź

${ }^{28}$ Por. Ajdukiewicz (1965): 24.

${ }^{29}$ Dybowski (2017c): 129.

30 Dybowski (2017c): 129-130.

31 Warto jednak powtórzyć, że w ramach budowanej przez Szkołę teorii przyjęto, że do zdań naczelnych tej teorii należą zdania opisujące związek między przepisem a normą prawną jako związek o charakterze treściowym, przy jednoczesnym wyraźnym rozróżnieniu przepisu od normy. 
jednoznacznie zinterpretowaną"32. Proponuje on, aby przypisując znaczenie wypowiedziom normatywnym, sens takich wypowiedzi ujmować przez podawanie wypowiedzi równoznacznych. Oznacza to, że norma prawna wyznaczajacca powtarzalną powinność podmiotom określonym nazwą generalna jest równoznaczna koniunkcji skończonej liczby „norm atomicznych”, będących de facto normami o charakterze indywidualnym i konkretnym ${ }^{33}$.

Przedstawione opracowanie byłoby niekompletne, gdyby pozostawić je bez choćby krótkiego omówienia poglądów dwóch innych autorów przynależących do Szkoły. W pierwszej kolejności Nowak wskazuje np. że „znaczenie jest szczególnego rodzaju sensem (celem) użytkowników języka. W takim razie pytanie, co znaczy wyrażenie w danym języku, jest pytaniem o to, jaki cel komunikacyjny wiąże (idealnego) użytkownika języka z użyciem tego wyrażenia. A w rezultacie jest to pytanie o humanistyczną interpretację zachowań językowych”34. Jak wskazuje Zieliński, „[Nowak - W.R.] mając to na uwadze, stworzył założenia niektórych prawniczych reguł wykładni tekstu prawnego”, pośród których wymienić należy założenie o racjonalności (doskonałości) prawodawcy ${ }^{35}$.

Nowak mówi o znaczeniu w y powiedzi nor maty w nej w sposób następujący: „znaczenie deskryptywne wypowiedzi normatywnej polega na tym, że wyznacza ona - ze względu na określone reguły semantycznego języka, do którego należy - pewien układ uporządkowany, który nazywam intensjonalnym stanem przedmiotowym wyznaczonym przez tę normę" ${ }^{36}$. Wskazuje on także: „stanem przedmiotowym wyznaczanym przez normę generalną [...] nazywam trójkę uporządkowaną (relacja czynienia, klasa faz $\mathrm{F} \frac{W}{t^{\prime}}$ osób o własnościach $\mathrm{W}$, zachowanie $\left.\mathrm{C}_{\left(\mathrm{t}^{\prime}\right)}\right)^{\text {" } 37}$. Wzorem zachowania jest zachowanie $\mathrm{C}_{\left(\mathrm{t}^{\mathrm{t}}\right)}$, jeżeli zostało wskazane przez normę $\mathrm{N}^{(\mathrm{t}) 38}$. Postuluje on nadto wprowadzenie do wskazanej trójki uporządkowanej intensji odpowiednich stałych oznaczajaccych adresata normy i zachowanie przez nią wskazane ${ }^{39}$.

Istotne podobieństwo zachodzi między ujęciem Nowaka a Patryasa. W przedstawionej przez tego ostatniego koncepcji „znaczeniem normy jest własność przysługująca jej i wszystkim normom z nią równoznacznym" ${ }^{40}$. Zachodząca między normami relacja równoznaczności możliwa jest, zdaniem Patryasa, dzięki przełożeniu argumentów normy. Przekład taki dokonywany jest na podstawie stosownej definicji. W konsekwencji „[...] norma i jej przekład mają ten sam zwrot normatywny oraz równoznaczne argumenty, więc

32 Ziembiński (1966): 122.

33 Por. Ziembiński (1966): 148.

${ }^{34}$ Nowak (1973): 34.

35 Zieliński (2017): 79. Jak wskazuje Zieliński, kolejną próbą zastosowania metod interpretacji humanistycznej była m.in. praca Patryas (1988). Szerzej o założeniu racjonalności (doskonałości) prawodawcy Nowak (1973).

36 Nowak (1966): 47.

37 Nowak (1966): 41.

38 Nowak (1966): 41.

39 Nowak (1966): 41.

40 Patryas (2001): 109. Autor uwagę tę umieścił w przyp. 233, natomiast swoją koncepcję znaczenia norm przedstawił na s. 108-110. 
i one są równoznaczne” ${ }^{41}$. Przy takim ujęciu wyrażenie „znaczenie językowe” rzeczywiście wydaje się szczególną funkcją przyporządkowującą argumentom norm przekładanych równoznaczne argumenty norm przełożonych. Jak jednak trafnie zauważa Patryas, ,język naturalny nie jest językiem w rozumieniu logicznej teorii" ${ }^{42}$, co w rzeczywistości oznacza, że tak zarysowana koncepcja musi zmierzyć się z tzw. argumentem Tarskiego. O ile wydaje się, że Patryas w odróżnieniu od stanowiska przyjmowanego w Szkole - nie odrzuca poglądu o możliwości ustalenia obiektywnego znaczenia normy na gruncie określonego języka, o tyle ceną za takie stanowisko jest przyjęcie kontrfaktycznej tezy, że język norm prawnych jest językiem sztucznym.

\section{WPLYW KAZIMIERZA AJDUKIEWICZA NA STANOWISKO SZKOLY}

Przy przypisywaniu normie prawnej znaczenia należy postępować podobnie jak przy odtwarzaniu norm z przepisów prawnych. Oznacza to konieczność zastosowania reguł interpretacyjnych właściwych dla przyjętej koncepcji wykładni. Norma prawna jako treść przepisów prawnych, określając powinność wyrażoną w przepisach, posługuje się słownictwem interpretowanych przepisów oraz słownictwem właściwym dla przyjętej koncepcji normy prawnej ${ }^{43}$. Uwidacznia się tutaj wyraźny wpływ filozofii Ajdukiewicza. Ten ostatni przez pojęcie języka rozumiał bowiem język $J$ o ustalonym słownictwie, regułach składni i związkach motywacyjnych, tzn. nadawaniu przedmiotom pewnej nazwy wobec stwierdzenia, że posiadają określone cechy ${ }^{44}$. Właśnie owe związi motywacyjne są przyczynkiem do mówienia o dyrektywach języka rozumianych jako wzory uznawania pewnych zdań za zdania danego języka ${ }^{45}$. Definicja znaczenia powstaje zaś przez samokrytyczne podejście do sformułowanej uprzednio przez Ajdukiewicza definicji równoznaczności. Proponuje on następującą intuicję: „dwie nazwy w danym języku znaczą to samo wtedy, gdy majac zaprezentowany przedmiot pod pewnym aspektem, gotowi jesteśmy do przedmiotu tego zastosować zarówno jedna, jak i drugą nazwę" ${ }^{46}$. Wydaje się więc, że owa gotowość zastosowania odpowiada omawianym wcześniej związkom motywacyjnym. Widać tutaj szczególnie, że Ajdukiewicz postrzega

41 Patryas (2001): 110.

42 Patryas (2001): 118.

${ }^{43}$ Przyjęta koncepcja normy określa np., że normą jest wypowiedź „nakazuje się podmiotom $X$ w okolicznościach $C$ zachować się w sposób $N$ '.

${ }^{44}$ Ajdukiewicz (2006a): 125, 128.

45 „Otóż dla każdego języka o ustalonych związkach motywacyjnych, tzn. dla każdego tak rozumianego języka, że aby nim umieć mówić, trzeba być zdolnym do uznawania jego zdań na odpowiedniej dla każdego kształtu zdania podstawie, dałaby się - teoretycznie rzecz biorac - sformułować dyrektywa określająca, jakie są dla każdego kształtu zdania odpowiednie motywy jego uznania" - Ajdukiewicz (2006a): 129-130.

${ }^{46}$ Ajdukiewicz (2006a): 132. 
znaczenie nazwy w kontekście uznawania zdań i prawidłowości posługiwania się daną nazwą. Pomijając tutaj krytykę Alfredra Tarskiego przedstawiona w postaci tzw. argumentu Tarskiego ${ }^{47}$, za Kazimierzem Ajdukiewiczem podać można definicję równoznaczności: „wyrażenie $A$ jest w języku $J$ równoznaczne z wyrażeniem $B$, to tyle, co: każde i tylko takie przeżycie $P$, z którego wedle dyrektyw języka $J$ daje się bezpośrednio i w sposób istotny dla wyrażenia $A$ wywieść dowolne zdanie $Z$ języka $J$, zawierające wyrażenie $A$, daje się też wywieść wedle dyrektyw języka $J$ bezpośrednio i w sposób istotny dla wyrażenia $B$ z uznania zdania powstającego ze zdania $Z$ przez zastapienie (wszędzie lub nie wszędzie) wyrażenia $A$ przez wyrażenie $B$ "48. Definicja znaczenia uzyskana przez abstrakcję z definicji powyższej „określałaby znaczenie danego wyrażenia $W$ w języku $J$ mniej więcej jako tę własność wyrażenia $W$, która jest wspólna wszystkim wyrażeniom $W$ w języku $J$ i tylko tym wyrażeniom" ${ }^{49}$. Powyższa koncepcja znaczenia sprowadza się do wymienialności używanych nazw i gotowości do uznawania zdań, w których taka wymienialność, zgodnie z powyższą definicja, może zachodzić.

Przenosząc powyższe ustalenia na grunt przyjmowanej w Szkole semantyki, można się posłużyć definicją równoznaczności Ajdukiewicza i stwierdzić, że: Wyrażenie należące do języka przepisów prawnych jest w języku prawnym równoznaczne $\mathrm{z}$ wyrażeniem języka norm prawnych, to tyle, co: każde i tylko takie przeżycie będące rozumieniem tekstu prawnego, z którego z dyrektyw języka prawnego ${ }^{50}$ daje się bezpośrednio i w sposób istotny dla wyrażenia należącego do języka przepisów prawnych wywieść dowolne zdanie należące do języka prawnego, zawierające wyrażenie należące do języka przepisów prawnych, daje się też wywieść wedle owych reguł znaczeniowych języka prawnego bezpośrednio i w sposób istotny dla wyrażenia należącego do języka norm prawnych z uznania zdania powstającego ze zdania należącego do języka prawnego przez zastapienie (wszędzie lub nie wszędzie) wyrażenia języka prawnego przez wyrażenie języka norm prawnych. Nie da się jednak z takiej definicji równoznaczności wyprowadzić definicji znaczenia norm, ponieważ definicję znaczenia zaprezentowana przez Ajdukiewicza stosuje się do języków sztucznych, tj. niezawierających wyrażeń niejednoznacznych. Takim zaś nie jest ani język przepisów prawnych, ani tym bardziej język norm prawnych.

Ajdukiewicz, zdając sobie sprawę z trudności dotyczącej semantyki języka naturalnego, zmienił pod koniec życia swoje myślenie o tym zagadnieniu. Można wręcz powiedzieć, że zwrot pragmatyczny w jego poglądach polegał na tym, że przesuną on ciężar rozważań z definiowania równoznaczności na problem gotowości podmiotu do uznania i odrzucania zdań.

To założenie omówił Jerzy Hanusek, wskazując, że „wyrażenia każdego zinterpretowanego języka, używanego przez społeczność językową w celach

47 Szerzej na ten temat Ajdukiewicz (2006b): 397.

48 Ajdukiewicz (2006a): 134.

49 Ajdukiewicz (2006a): 134.

${ }^{50}$ Moim zdaniem są to reguły znaczeniowe właściwe językowi naturalnemu i modyfikujące albo zastępujące je reguły znaczeniowe właściwe dla danej koncepcji wykładni. 
komunikacyjnych, posiadają znaczenia rozpoznawalne przez użytkowników języka [wyróżnienie - W.R.]. W przeciwnym wypadku komunikacja nie byłaby możliwa. Dla każdego takiego języka istnieje relacja równoznaczności między wyrażeniami, którą jego użytkownicy intuicyjnie rozpoznają i wykorzystują w praktyce językowej”"51. Tak wyraźne skupienie się na pragmatycznych pojęciach uznawania i odrzucania zdań świadczy zaś o nowoczesności prezentowanych koncepcji ${ }^{52}$.

\section{PRAGMATYZM ANALITYCZNY WOBEC PROBLEMU ZNACZENIA JĘZYKOWEGO NORMY PRAWNEJ}

Filozofowi Johnowi Wisdomowi przypisuje się autorstwo zdania, że: „można filozofować o wtorku, funcie szterlingu, pastylkach do ssania i o samej filozofii. Jest tak dlatego, że filozof analityczny, w przeciwieństwie do naukowca, nie poznaje nowych prawd, lecz na nowo ujmuje stare prawdy"53. Zdanie to w pewien sposób tłumaczy, dlaczego metody analityczne, z całym bogactwem swoich odmian, stanowiły najlepsze narzędzie do zmierzenia się z problemem znaczenia językowego norm prawnych. Filozofia analityczna dała teoretykom prawa narzędzia, którymi można było dokonać rozbioru zastanej całości - prawa - na jego elementy składowe ${ }^{54}$. Pozwoliła zaprowadzić porządek terminologiczny w prawoznawstwie oraz uchwycić w formie pojęć dotąd jedynie intuicyjnie postrzegalne konstrukty czy zjawiska. W Szkole przejęta niemalże w pełni została idea szkoły lwowsko-warszawskiej, o której Izydora Dąmbska pisała w sposób następujący: „Postulatem naczelnym, konsekwentnie przez przedstawicieli szkoły w ich pracach realizowanym, był postulat stosowania $\mathrm{w}$ badaniach filozoficznych metod analizy semantycznej i logicznego dyskursu przy równoczesnym docenianiu w procesie wykrywania twierdzeń szeroko rozumianej intuicji; postulat jasności, precyzji i poprawności logicznej w formułowaniu zagadnień, twierdzeń i argumentów, i w definiowaniu pojęć; wreszcie postulat krytycyzmu i antydogmatyzmu w ocenie założeń teoretycznych"55.

Na zakończenie chciałbym jednak zwrócić uwagę na szczególny kierunek obecny w filozofii języka, tj. kierunek nazywany przez Roberta B. Brandoma pragmatyzmem analitycznym, a także zasygnalizować, jakie możliwości daje teorii prawa odniesienie się do jego osiagnięć.

Pragmatyzm analityczny, co wynika już z samej nazwy kierunku, nie zrywa z tradycją analityczna, lecz stara się przezwyciężać napotkane trudności. Brandom wskazuje: „projekt analizy można uważać za nieudany z wielu różnych powodów. Moim zdaniem, ważne jest, by je od siebie odróżnić. Istotnym

51 Hanusek (2012): 163.

52 Szerzej na ten temat Nowaczyk (2000): 101-113.

53 Podaję za Szubka (2009): 13, wraz z przypisem do tego cytatu.

${ }^{54} \mathrm{O}$ analizie jako rozbiorze czegoś na elementy składowe Szubka (2009): 37.

55 Dąmbska (1989): 29. O szkole lwowsko-warszawskiej jako nurcie filozofii analitycznej zob. Szubka (2009): 71-73. 
elementem przedsięwzięcia, które podjąłem w niniejszych wykładach, jest odpowiedź na najcięższy, najgłębszy i najważniejszy zarzut, jaki sformułowano pod adresem jego klasycznej odmiany. Chodzi mianowicie o zestaw obiekcji, które wysunęli pragmatyści, z Wittgensteinem na czele"56.

W odniesieniu do analitycznych teorii prawa byłby więc pragmatyzm analityczny filozofia, która nie neguje dotychczasowych osiagnięć tych teorii, lecz proponuje zastępować narzędzia stare, o ograniczonych możliwościach, ich udoskonalonymi odmianami. W odniesieniu do zarysowanej tu problematyki wystarczy zwrócić uwagę choćby na Brandomowski pragmatyzm semantyczny, którego założenia oddają następujące słowa jego autora: „Rozważania pragmatystyczne nie powinny sprawić, że porzucimy semantykę i zajmiemy się wyłącznie pragmatyka. Wręcz przeciwnie, zrozumienie uwarunkowań praktycznych może pogłębić nasze rozumienie tej dyscypliny. [...] Podchodząc analitycznie do propozycji pragmatystów, możemy traktować badanie praktyki jako źródło szczególnych zasobów dla rozwoju i rozbudowy analitycznego rozumienia semantyki. Rozwój tej dziedziny polegać może na tym, że nie będzie się ona skupiać wyłącznie na znaczeniu, lecz także podejmie kwestię związków między znaczeniem a użyciem"57.

Do analitycznie ujmowanego problemu znaczenia językowego tekstów prawnych (pośrednio więc także do znaczenia językowego norm prawnych), odniósł się Dybowski. Używając Brandomowskiej terminologii, wskazał on, że „rozróżnienie to [na przepis prawny i normę prawną - W.R.] traktować można właśnie jako ustalenie relacji analizy między słownictwem bazowym a słownictwem docelowym, w której słownictwem uprzywilejowanym (bazowym) jest słownictwo norm prawnych, stanowiace rezultat zastosowania logiki nazw i logiki zdań do zbudowania syntaktycznego wzorca normy. W słownictwie owego wzorca dokonuje się przekładu słownictwa przepisów prawnych" ${ }_{58}$. Zauważony został więc problem słownictwa norm, które jest zasobniejsze od słownictwa przepisów. W powyższym sensie na słownictwo docelowe składa się m.in. słownictwo przepisów prawnych. By pojmować znaczenie normy w duchu pragmatyzmu analitycznego, należałoby wyznaczyć dla owego przekładu „szerszy praktyczny kontekstu działania, w którym treść pojęciowa się wytwarza” ${ }^{59}$. W tym sensie „to akt, działanie, praktyka ma odgrywać zasadniczą rolę w wyjaśnianiu pojęciowej treści i należy się jej - jak to określa Brandom - eksplanacyjne pierwszeństwo wobec semantyki”60.

Dybowski określa stanowisko semantyczne przyjmowane w Szkole mianem semantyki „środkowego biegu” (midstream semantics), „ponieważ [...] ustalenie treści wyrażeń językowych zależy przede wszystkim od reguł przekładu, które służą jako pośrednik między poprzednikami a ostatecznymi re-

56 Brandom (2012): 319.

57 Brandom (2012): 13.

58 Dybowski (2017a): 20.

59 Tak interpretuje myśl Brandoma Zarębski (2013): 33.

60 Zarębski (2013): 34. Szerzej o możliwości wykorzystania pragmatyzmu analitycznego w teorii wykładni np. Canale, Tuzet (2007): 32-44; Klatt (2004); (2008). 
zultatami”' ${ }^{1}$. Moim zdaniem takie postawienie problemu oznacza konieczność zwrócenia szczególnej uwagi na tezę, że źródłem reguł znaczeniowych w grze językowej nazywanej prawem jest kultura prawna. Kulturę prawną rozumiem przy tym jako zbiór praktyk, w ramach którego szczególną rolę pełni praktyka posługiwania się słownictwem języka prawnego i prawniczego. W tym sensie badanie kultury prawnej oznaczałoby również badanie sposobu tworzenia reguł znaczeniowych owej gry językowej, w tym także założeń przypisywanych tym regułom ${ }^{62}$.

Praktyka posługiwania się normami prawnymi jako elementami języka różni się w co najmniej jeden zasadniczy sposób od praktyki języka naturalnego. Okazuje się bowiem, że konstrukcja obrotu prawnego uprzywilejowuje niektórych jego uczestników, dając im możliwość arbitralnego określenia czy przypisanie znaczenia nastapiło $\mathrm{w}$ sposób prawidłowy ${ }^{63}$. Należałoby więc zastanowić się, jak pogodzić to z Brandomowskim programem, ponieważ za pozostającym w kręgu pragmatyzmu analitycznego Jaroslavem Peregrinem, można powtórzyć: „powiedzieć, że wyrażenie ma takie a takie znaczenie to $\mathrm{w}$ istocie powiedzieć, że powinno ono być używane w określony sposób”64. Uprzywilejowanie wybranych uczestników praktyki językowej byłoby więc równoznaczne z przyznaniem im swoistej władzy absolutnej na poziomie semantycznym. Program Brandoma jest atrakcyjny dla analitycznych teorii prawa także ze względu na podjęcie problemu intersubiektywności czy obiektywności wiedzy i oferuje w tym zakresie próbę odpowiedzi na pytanie: ,jak to możliwe, aby cała społeczność językowa była w błędzie co do własnych przekonań?"

Dybowski upatruje dobrej alternatywy dla semantyk jednostronnych w pragmatyzmie inferencyjnym. Zastrzega on jednocześnie, że „prawo wpisuje się w ten szeroko inferencyjny obraz semantyki, pod warunkiem, że gdy prawnicy stosują pojęcia prawne (kiedy angażują się w prawną praktykę dyskursywna) pozostaja w ramach danej autonomicznej praktyki dyskursywnej w języku naturalnym" ${ }^{66}$. W tym ujęciu praktyka generowania znaczenia językowego normy zakłada możliwość jego wykorzystania w ramach rozumowań praktycznych ${ }^{67}$. Jego zdaniem kolejność wyjaśniania przebiega tutaj od praktyk poszukiwania racji prawnych dla działań do twierdzeń, które kodyfikuja takie praktyki przez udzielanie licencji pewnym wnioskom jako wyraźnie prawnym ${ }^{68}$.

${ }_{61}$ Dybowski (2018): 36 („It may be called midstream semantics because [...] fixing the content of linguistic expressions depends primarily on the transformational rules that serve as an intermediary between antecedents and final results").

62 Pogląd ten został także skomentowany przez Dybowski (2018): 36.

${ }^{63}$ Mam tutaj na myśli np.: sąd i strony postępowania, organ wydajacy interpretację prawa podatkowego i wnioskodawcę.

${ }^{64}$ Peregrin (2012): 499 (,,To say that an expression means thus and so is essentially to say that it ought to be used in a certain way").

${ }^{65}$ Zarębski (2013): 278.

66 Dybowski (2018): 44.

67 Dybowski (2017b): 62.

68 Dybowski (2017b): 62. 


\section{$* * *$}

Stanowisko dotyczące znaczenia językowego na gruncie dorobku Szkoły wynikało z założenia, że pomiędzy przepisem prawnym a normą prawną istnieje związek o charakterze treściowym oraz z wyraźnego rozróżnienia przepisu od normy i wskazania reguł odtwarzania norm na podstawie przepisów. Wpływ filozofii Ajdukiewicza na Szkołę, a także pragmatyczne przesunięcie, które dokonało się w jego myśleniu pod koniec jego życia, skłania do skonfrontowania dorobku Szkoły z wyzwaniami pragmatyzmu. Ukryte jest tutaj oczekiwanie, że owocem spotkania tych dwóch nurtów byłoby, choćby częściowe, rozwiązanie trudności epistemologicznych przejawiających się w analitycznych teoriach prawa.

Pragmatyzm analityczny - tu jedynie wzmiankowany - wydaje się zachęcajacca propozycją rozwiązywania problemów, które napotykają analityczne teorie i filozofie prawa, a także te teorie i filozofie, które choć nie są umieszczane w gronie analitycznych, to jednak korzystaja z analitycznej aparatury do podejmowania wybranych przez siebie problemów. Wartościowe w tym względzie wydają się tezy Brandoma, który nie zarzucając rozważań nad semantyka, proponuje badać praktykę językową i traktować ją jako podstawę wzrostu dla ujmowanej analitycznie semantyki. Przeniesienie tych rozważań na grunt prawa musi uwzględniać różnice związane z prawną praktyką językowa, w szczególności z niesymetrycznością uprawnień dyskursywnych podmiotów grających w grę językową „prawo”.

Wojciech Rzepiński

Uniwersytet im. Adama Mickiewicza w Poznaniu

wojciech.rzepinski@amu.edu.pl

https://orcid.org/0000-0002-9314-8818

Ajdukiewicz, K. (1965). Logika pragmatyczna. Warszawa.

Ajdukiewicz, K. (2006a). O znaczeniu wyrażeń, [w:] K. Ajdukiewicz, Język i poznanie. Tom 1. Warszawa: 105-134 [= K. Ajdukiewicz. O znaczeniu wyrażeń, [w:] Księga Pamiątkowa Polskiego Towarzystwa Filozoficznego we Lwowie. Lwów 1931: 31-77].

Ajdukiewicz, K. (2006b). Zagadnienie empiryzmu a koncepcja znaczenia, [w:] K. Ajdukiewicz, Język i poznanie. Tom 2. Warszawa: 388-400 [= K. Ajdukiewicz. Zagadnienie empiryzmu a koncepcja znaczenia. Studia Filozoficzne 36(1), 1964: 3-14].

Brandom, R.B. (2012). Między mówieniem a działaniem. W stronę analitycznego pragmatyzmu. Tłum. M. Gokieli. Warszawa.

Canale, D., Tuzet, G. (2007). On legal inferentialism: toward a pragmatics of semantic content in legal interpretation? Ratio Juris 20(1): 32-44.

Czepita, S. (2010). Derywacyjna koncepcja wykładni a zagadnienie otwartej tekstowości pojęć prawnych, [w:] A. Choduń, S. Czepita (red.), W poszukiwaniu dobra wspólnego. Księga jubileuszowa Profesora Macieja Zielińskiego. Szczecin: 227-255.

Czepita, S., Wronkowska, S., Zieliński, M. (2013). Założenia szkoły poznańsko-szczecińskiej w teorii prawa. Państwo i Prawo 68(6): 3-16.

Dąmbska, I. (1989). O niektórych koncepcjach metafilozoficznych w szkole lwowsko-warszawskiej, [w:] J. Perzanowski (red.), Jak filozofować? Studia z metodologii filozofii. Warszawa: 22-29.

Dybowski, M. (2017a). Teoria prawa wobec wyzwań pragmatyzmu analitycznego. Archiwum Filozofii Prawa i Filozofii Społecznej 14(1): 17-33. 
Dybowski, M. (2017b). Transition to democracy and determinacy of legal concepts, [w:] B. Fekete, F. Gárdos-Orosz (eds.), Central and Eastern European Socio-Political and Legal Transition Revisited. Frankfurt am Main: 57-74.

Dybowski, M. (2017c). Uwagi o pragmatycznej roli definicji legalnych w derywacyjnej koncepcji wykładni prawa, [w:] M. Hermann, S. Sykuna (red.), Wykładnia prawa. Tradycja i perspektywy, Warszawa: 115-130.

Dybowski, M. (2018). Articulating ratio legis and practical reasoning, [w:] M. Dybowski, V. Klappstein (eds.), Ratio Legis. Philosophical and Theoretical Perspectives, Heidelberg: 29-55.

Hanusek, J. (2012). Argument Tarskiego i dwie teorie znaczenia Kazimierza Ajdukiewicza. Diametros 32: 160-189.

Klatt, M. (2004). Theorie der Wortlautgrenze: Semantische Normativität in der juristischen Argumentation. Baden-Baden.

Klatt, M. (2008). Making the Law Explicit: The Normativity of Legal Argumentation. OxfordPortland.

Nowak, L. (1966). O znaczeniu wypowiedzi normatywnych, [w:] Naturalistyczne i antynaturalistyczne interpretacje humanistyki. Poznań: 27-52.

Nowak, L. (1973). Interpretacja prawnicza. Studium z metodologii prawoznawstwa. Warszawa.

Nowaczyk, A. (2000). Ajdukiewicza teoria znaczenia z perspektywy lat. Filozofia Nauki 8(2): 101-113.

Patryas, W. (1988). Interpretacja karnistyczna. Studium metodologiczne. Poznań.

Patryas, W. (1997). Definiowanie pojęć prawnych. Poznań.

Patryas, W. (2001). Rozważania o normach prawnych. Poznań.

Peregrin, J. (2012). Semantics without meanings? Sellarsian "patterned governed behavior" and the space of meaningfulness, [w:] R. Schantz (ed.), Prospects for Meaning, Berlin: 479-501.

Szubka, T. (2009). Filozofia analityczna. Koncepcje, metody, ograniczenia. Wrocław.

Wronkowska, S. (2010). Zygmunt Ziembiński, [w:] T. Buksiński (red.), Filozofia na Uniwersytecie w Poznaniu. Poznań: 335-346.

Wróblewski, J. (1959). Zagadnienia teorii wykładni prawa ludowego. Warszawa.

Zarębski, T. (2013). Neopragmatyzm Roberta B. Brandoma. Kraków.

Zieliński, M. (1972). Interpretacja jako proces dekodowania tekstu prawnego. Poznań.

Zieliński, M. (2017). Wykładnia prawa. Zasady, reguły, wskazówki. Warszawa.

Zieliński, M., Ziembiński, Z. (1988). Uzasadnianie twierdzeń, ocen i norm w prawoznawstwie. Warszawa.

Ziembiński, Z. (1960). Przepis prawny a norma prawna. Ruch Prawniczy, Ekonomiczny i Socjologiczny 22(1): 105-122.

Ziembiński, Z. (1966). Logiczne podstawy prawoznawstwa. Warszawa.

Ziembiński, Z. (1974). Metodologiczne zagadnienia prawoznawstwa. Warszawa.

Ziembiński, Z. (1980). Problemy podstawowe prawoznawstwa. Warszawa.

Ziembiński, Z. (2002). Logika praktyczna. Warszawa.

Znamierowski, C. (1934). Podstawowe pojęcia teorji prawa. Część 1: Układ prawny i norma prawna. Wyd. 2. Poznań.

\author{
THE LINGUISTIC MEANING OF A LEGAL NORM \\ IN THE POZNAN-SZCZECIN SCHOOL OF LEGAL THEORY \\ IN THE LIGHT OF ANALYTIC PRAGMATISM
}

Sum mary

The author first reconstructs standpoints adopted by the scholars from the Poznan-Szczecin school of legal theory regarding the linguistic meaning of a legal norm. This reconstruction allows certain dilemmas related to the adoption of analytic philosophy in the theory of law to be visualized. In the next section of the article, attention is paid to the influence of Kazimierz Ajdukiewicz's philosophy on the understanding of linguistic meaning within the School. The problem of linguistic 
meaning may be explained by the definition of equivalence, the core of which is a set of directives of a specific language. Finally, the author comments on the theses of Robert B. Brandom's analytic pragmatism and the application of the latter to legal theory of Maciej Dybowski. Analytic pragmatism extends semantic research through an attempt to understand practice-related conditions.

Keywords: legal norm; linguistic meaning; analytic pragmatism; Poznan-Szczecin school of legal theory 
